\title{
The Doctrine of Intentionality in Merlau-Ponty
}

\author{
Agama Christina Sunday $(\mathrm{PhD})$ \\ Directorate of General Studies, Federal University of Technology, Owerri
}

\begin{abstract}
The focus of this paper is to examine the doctrine of intentionality in Merleau-Ponty. It will look at how he departs from the traditional description of intentionality. It will also draw the differences between his and Husserls understanding of Intentionality, and how his doctrine of intentionality becomes integral to subjectivity. This discourse submits that MerleauPonty's phenomenological approach to intentionality amounts to radicality especially from his account of the intentional constitution of the body and its role in perceptual experience.
\end{abstract}

Keywords: Internationality, Consciousness, embodiment, perception, phenomenology

\section{INTRODUCTION}

$I^{n}$ philosophy, the concept of intentionality is very central more especially in phenomenology. Accordingly, Husserl says that intentionality is the fundamental property of consciousness and the principle theme of phenomenology. Yet, the concept of intentionality appears so technical in philosophy, while in the other way round, it is a familiar term even to those outside philosophy. Its central character is to our mental states and experiences, more especially when we claim to be conscious or aware of something else. Consciousness is to humanity. Man is not completely affected by all that surrounds him simply because of his consciousness. He is always conscious of things around him, including himself. The mental life of man like hopes, thoughts, beliefs, perceptions etc, gives him a sense of something in his world. This mental state or experiences of the mind or consciousness is "internationality" and/or the ability of consciousness to be about things is known as "intentionality"

However, the term intentionality is from a Latin verb intendo meaning to aim, hold out, or stretch. To this effect, intentionality refers to the way the state of the mind (consciousness) can aim at or be directed towards both intentional (as in images, memories, feelings etc) and external (like physical things, relations, events etc) objects. The mental states of man are always of or about something. In other words, consciousness is consciousness of something. It is never empty.

From this position, intentionality becomes a conceptual tool that is used by many scholars with different aims and backgrounds in explaining how human beings get to know fully nature of the world and how to meet up with their needs. Meanwhile, the doctrine of intentionality in Merleau-Ponty is to be discussed in this paper. Merleau-Ponty develops the concept of intentionality in respect to embodiment. He argues that the external world or rather what he calls the "primary world" can only be accessed through our lived bodies. For him, the world cannot be if our bodies do not exist and as such the concept of lived body becomes central to his doctrine of intentionality.

According to Merleau-Ponty, there is no separation between the world and the lived body. Both of them are tied together through what he calls intentional arc. It is this international arc that binds the body to the world such that the movement of the lived body creates space. This movement of the body is not the objective one, but the experience of this movement. The things we think and experience- and the way we think and experience them-reflect aspects of the physical structure of our body as well as the things our body can do. Therefore, intentionality is embedded in our bodies and agency. This motor dimension has to be part of a full picture of intentionality ${ }^{1}$. The feeling of our body (ie Kinaesthesia) and its surroundings is not just an exercise in self-relation but the process at which we in his own word, "prehend" the world. This kinaesthetic feedback is the means by which we both objectify the world and orient ourselves within it. Our bodysubject is directed towards the word and cannot in any way be separated from this field of action in the world. Therefore, intentionality for Merleau-Ponty is the pre-reflective moving body which is in itself intentional and at the same time reaching out towards the world.

\section{MERLEAU PONTY'S PRECOGNITIVE BACKGROUND OF INTENTIONALITY}

The traditional rationalism as championed by Descartes had maintained that the human mind exist in togetherness with the way things in the world really are. This tradition has it that the human mind is in the form such that it is capable of grasping what really exists for what exists is what is known. So this tradition of rationalism emphasizes the difference between the physical world which we perceive and the basic reality of things which is beyond our perception. According to Descartes, it is the mind which is different from the body (a thing that thinks) has the capacity to represent true reality as if the mind is a mirror reflecting what exists in nature. However, Merleau Ponty wondered how intellectual certainty or the underlying reality of things could be located in the mind independent of the body. This inspired Merlaeu Ponty to embark upon a new way of thinking about relation of the mind to meaning, about the primacy of perception.

Merleau Ponty in contrary to Descartes explains that our knowledge is the product of our body's perception of the world. Knowledge is not possible without the activity of our body. Human body brings about the possibility of knowledge attainment to everything that exists. The interaction of the body to the things of the world, its perception is immediate. 
There is no separation between our body's perception and our conscious perception. Both the body and the mind are naturally attached to each other. None of them has ever existed before the other. So what is immediately given to us through perception is the basic material upon which our thought is grounded. In other words, consciousness is always a consciousness of something. Besides, the mind does not at first exist by itself as a blank without any content, as implied in Descartes' description of the mind. He discards Descartes ideal notion of the thinking being - as a real thing, and really existent. So Merleau Ponty claims that the Cogito is always accompanied by a Cogitatum. He avers that Descartes was wrong by declaring the self as a "mind" different from the world. It is rather the body which is the outstanding means of achieving the reality of things in the world. For him, therefore, the true cogito should be the one that must reveal oneself in a situation as being in the world. So the perceiving thing (or object) should be able to be embodied or have the mixture of soul and body.

Meanwhile, Merleau Ponty's doctrine of intentionality cannot be well understood without tracing first the notion of intentionality from his predecessors. This pre-requisite will simply enable us to fish out the implicit similarities and differences between Merleau Ponty and Husserl understands of intentionality (his immediate man and how Merleau-Ponty departs from Husserl's program of the doctrine.

Most phenomenologists make up their distinctive feature of intentionality from Brentano. It was Brentano who came up with what he calls "descriptive psychology" (at times he calls it "phenomenology"). A stand at which he gives a descriptive analysis of experience from the inside. ${ }^{2}$ Brentano maintains that in order to have this descriptive analysis of experience, intentionality remains the central part of such project. For him, intentionality is out rightly a mental phenomenon. It is not in any way a physical phenomenon and there is no physical phenomenon that performs similar function like that of intentionality because it is just a mental phenomenon. In his own words, intentionality "is characteristic exclusively of mental phenomena. No physical phenomena exhibit anything like it. We can, therefore, define mental phenomena by saying that they are those phenomena which contain an object intentionality within themselves" 3 . He has it that intentionality is so unique in its character in such that it gives individuals mental states their distinguishable character. Thus, he says: "Every mental phenomenon includes something as an object within itself, although they do not all do so in the same way. In present action something is presented, in judgment something is presented, in judgment something is affirmed or denied, in love loved, in hate hated, in desire desired, and so on"4. The above passage deductively has three important points which summarizes the characteristics of intentionality in accordance with Brentano. First, that intentionality is exhibited by judging, perceiving, hoping, believing etc. all these mental states according to him are directed towards something. The second one is what he calls intentional inexistence which is the characteristics of the objects towards the mind as directed by the virtue of intentionality. Finally, intentionality possesses the mark of mentality through which all mental states display intentionality. In other words, intentionality for him is what defines the characteristics of the mental which means, all and only and mental phenomena are intentional.

Husserl's doctrine of internationality though was inspired by his master's meaning of intentionality-Franz Brentano of Merienbery but Husserl takes it to a high level- the transcendental. It is a transcendental relation of the mind to any given object. The mind in creating the meaning of the object creates itself. For Husserl, intentionality not only brings out relationships, it does the higher function of constructing and constituting the object of intention in their meaningfulness. It is intentionality that gives meaning to objects. For instance, when the human spirit form a triangle from the heights of three objects, a reality is created mentally, which does not exist in the actual sense. According to Husserl, what gives sense to a thing or an expression is the intention of meaning. Intentionality constitutes knowledge of reality. Without intentionality, everything is meaningless even when there is consciousness, because Husserl believes that the essence of consciousness is intentionality. One can lose consciousness while the content of the reality remains. One can come back consciously to that content for many times like margining, judging and remembering, due to the possibility of intentionality.

Husserl further describes another important feature of intentionality saying that intentionality is not a passive state whereby the external world forces itself as in onto a surrendering observer. That intentionality "wants to go to the object itself...that is, to an intuition that is in itself the consciousness of having the object itself ${ }^{\text {"5 }}$. This has made it a dynamic, temporally extended activity through which it actualizes its satisfaction. "This directedness is...a striving; it is from the very beginning driving at a satisfaction". However, the assertional claim of Husserl here is in line with Bower and Gallagher 2013; Hurley 1998; Noe 2004; Thompson 2005, whose the contemporary enactive approaches to perception stress the interdependence of perception and action. Husserl claims that we can understand this feature of our experience by looking at the intentional structure of perception's "striving" character.

\section{MERLEAU PONTY'S PRIMACY OF INTENTIONALITY}

The degree at which the concept of intentionality is placed in Merleau Ponty is in part an endorsement of Husserl's sensitive to the role embodiment plays in shaping the character and content of intentionality. But Merleau Ponty takes this idea further and rejects all attempts to reconstruct objective awareness out of the mere subjective stuff of sensation. At least, a fee passages from the preface of phenomenology of perception are enough to indicate just how far Merleau-Ponty 
departs from Husserl's program, both in broad outline and in fine detail. He makes different points from Husserl by indicating that "the greatest lesson of the reduction is the impossibility of a complete reduction" 6 . Moreover, referring specifically to the "eidetic" reduction, he continues:

The need to proceed by way of essences does not mean that philosophy takes them at its objects, but on the contrary that our existence is too tightly caught up in the world to know itself as such at the point where it casts itself forth, and that it needs the field of ideality in order to come to know and prevail over its facticity ${ }^{7}$.

Merleau Ponty also criticizes the ideality of "pure" consciousness and the reality of "opaque" sensation figure prominently in Husserl's phenomenology as remnants of the rationalist and empiricist traditions in epistemology. Actually, Husserl is not an empiricist in the traditional sense, since he does not think that the immediate objects of our awareness are anything like sensations. While on his part that is, giving out the distinction between real and ideal, Merleau Ponty maintains that:

The material and form of knowledge are artifacts of analysis. I posit a material of knowledge when, breaking, away from the original faith of perception, I adopt critical attitude toward it and ask myself, what am I really seeing? ... Neither object nor subject is posited . $^{8}$.

Indeed, one's awareness does not present itself to him as an immanent sphere over against transcendent objects, rather "the perception of our own body and the perception of external things provide an example of nonpositing consciousness", The logic of everyday experience, far from constituting "ideal essence" in the domain of transcendental subjectivity is "a logic lived through that cannot account for itself", its meaning "an immanent meaning that is not clear to itself and that becomes fully aware of itself only through the experience of certain natural signs" 10 .

This notion of the "natural signs" mediating our perceptional experience is an allusion to Husserl's concept of motivation, though Merleau ponty appropriates the notion for his own phenomenological purpose.

The phenomenological notion of motivation is one of those "fluid" concepts that must be formed if we want to get back to the phenomena. One phenomenon releases another, not by some objectives efficacy, like that which links events in nature, but by the meaning it offers- there is a raison d'etre that orients the flux of phenomena without being explicitly posited in any one of them a sort of operant reason ${ }^{I I}$.

Hence, his causal reliance on notions like reason, thought and entailment, Merleau Ponty did not conceive them as motivation, like Husserl, as either a hypothetical inference or an association of sensations, but rather to the ongoing unconscious preservation of a balance or gestalt in our bodily orientation in the world. For our bodies are constantly and tacitly adjusting themselves to integrate our experience and maintain our effective grip on things. According to him:

My body is geared to the world when my perception offers me a spectacle as varied and as clearly articulated as possible, and when my motor intentions, as they unfold, receive from the world the responses they anticipate. This maximum distinctness in perception and action defines a perceptual ground, a basis of my life, a general milleu for the coexistence of my body and the world ${ }^{12}$.

The situatedness of our bodies in perception is not at bottom an object of judgment, inference, or even conscious awareness. It is instead the spontaneous, self-correcting, precognitive background of intentionality because "our body is not the object of an 'I think': it is an ensemble of lived meanings that finds its equilibrium ${ }^{13}$.

The 'natural signs' mediating our embodied perceptual experience, then, are neither transparent mental contents interior to consciousness nor objective external events, but lie instead in our precognitive bodily engagement with the world. Perceptual experience incorporates the movements of the body and spontaneously takes them into account in opening us onto a stable external world. Perception is always informed, that is, by what Merleau-Ponty calls a "body schema" (Schema Corporel), which consists neither in a mental attitude in a mere physiological state. He conceives the body schema as a condition of cognition, not as a product, for it is only by being embodied that one becomes a subject in the world. According to Merleau Ponty, "I am conscious of my body via the world" he says, just as "I am conscious of the world through the medium of my body"14. My body is not a mere container or instrument of my agency, rather it comprises "stable organs and pre-established circuits"15 that function according to their own logic, as it were below the threshold of conscious intention.

The body schema is therefore "neither the mere copy nor even the global consciousness of the existing parts of the body". Rather, it is "dynamic", that is, "my body appears to me as an attitude with a view to a certain actual or possible task" Putting the point more vividly, Merleau Ponty writes, "if I stand in front of my desk and learn on it with both hands, only my hands are stressed and the whole of my body trails behind them like the tail of a comet"17. And it is a practical background familiarity with the world itself that informs our intentional familiarity with our bodies: "I know where my pipe is with absolute certainty, and thereby I know where my hand is and where my body is" ${ }^{\prime 1}$. The body is not an object of which I have an internal image or internal representation, rather "it is polarized by its tasks, because it exists towards them, because it gathers itself up to reach its goal, and 'body schema' is in the end a way of saying that my body is in the world" 19 . For him therefore, my body simply "is my point of view on the world" ${ }^{20}$. The body, then, is a permanent structure of perception, over and beyond the peculiar features of any one of the five traditionally differentiated senses. Perception is 
holistic, and the body's background self-awareness is one of its permanent horizons. External perception and the perception of one's own body vary in conjunction because they are the facets of one and the same act ${ }^{21}$.

From the above analysis, however we have seen that Merleau Ponty's argument is that we are basically animate bodies open and responsive to a meaningful environment. This our body that is open makes up what we are as a being-in- the world. And this openness means that our embodied being is intentional all throughout the body system including prenoetic levels of worldly engagement ${ }^{22}$. Hence, Merleau Ponty considers this as a "profound" intentionality "beneath the intentionality of representation"23.

Merleau Ponty maintains that in everyday life, we ordinarily and most often act in an organized and deliberate way without consciously reflecting, planning or even fully be aware of the act. This observation leads him to introduce the concept of what he calls "motor intentionality". Motor internationality refers to the integrated suite of skills, capacities, and habits not all of which are available to consciousness - that enable this reflective action ${ }^{24}$. It picks out a way of being directed toward the noetic structure of mental intentionality.

Meanwhile, the concept of motor intentionality' in one way or the other becomes synonymous with Merleau-Ponty's description of the body's role in the comprehension of perceptual sense as this dimension of intentionality according to him, is embedded in our embodiment. The embodiment herein is in such that we don't wholly bedwell our bodies as objects, nor as physical things having similar properties with other objects in the world. But we live through our bodies onto the world; we experience them from the inside as subject $^{25}$. Therefore, motor intentionality is more of intentional vehicle that allows us to be immediately open and responsive to the things happening around us. Thus, he proclaims that "these elucidations enable us to understand motility and basic intentionality. Consciousness is in the first place not a matter of 'I think that' but of 'I can ${ }^{26}$.

Above all, intentionality for Merleau Ponty is a direct and spontaneous rection of the body to the things in the world. What makes the body intentional is nothing but its relation and its movement toward various things in the world. This relation or movement is not conscious or planned before hand. Any of the action is direct and spontaneous. When once there is an obvious move of the body, unexpected movement especially as a result of danger (like touching a hot pressing iron), is for him intentional.

\section{CONCLUSION}

In the above discussion, Merleau Ponty recognizes the body as where consciousness and reality occupy the same conceptual space. Unlike the classical view of intentionality championed by Brentano whereby intentionality is taken to be the mind's ability to be directed towards mental object. He rather argues that motricity should be understood as original intentionality because of it's an embodied activity. Thus, he rejects the claim as in accordance with Husserl's early intentional analysis that intentionality is explained by mental activity. For him, intentionality is not a unidirectional mental activity. Likewise, the fully claimed knowledge of us as embodied agents is not by cognitive achievement as Husserl affirms but by abiding structure of perceptual experience. Merleau Ponty also turns down Husserl's motivational concepts like reason, thought, and entailment as either a hypothetical inference or an association of sensations. He rather places them as an ongoing unconscious preservation of a balance or gestalt in our bodily orientation in the world. He asserts that our bodies are always adjusting themselves to embody our experience and maintain our effective grip on things. In other words, all experience is for him fundamentally intentional and meaning is constituted in embodied experience.

\section{ENDNOTES}

[1] See Krueger, J. The Oxford Handbook of Phenomenological psycho-pathology. 10.1093/oxfordhb/9790198803157.013.37.Mar.2018, P.4.

[2] See Brentano, F. Descriptive Psychology, Trans B. Muller. London: Routledge 1995a.

[3] Brentano, F. Psychology from an Empirical standpoint, trans. A.C. Rancurello, D. Terrell, and L.L. McAlister. London and New York: Routledge. 1995b, P.68.

[4] Ibid.

[5] Husserl, E. Analysis Concerning Passive and Active Synthesis: Lectures on Transcendental Logic, Trans. A.J. Stainbock Dordrecht: Kluwer Academic Publishers. 2001, P.126.

[6] Merleau Ponty, M. Phenomenology of Perception, trans. Colin Smith, London: Routledge \& Design Paul 1962, P XIV.

[7] Ibid; P. XIV-XV

[8] Ibid; P. 241

[9] Ibid; P. 49

[10] Ibid

[11] Ibid; P.49-50

[12] Ibid; P.250

[13] Ibid; P.153

[14] Ibid; P.82

[15] Ibid; P. 87

[16] Ibid; P.100

[17] Ibid

[18] Ibid

[19] Ibid; P.101

[20] Ibid; P.70

[21] Ibid; P.205

[22] See Gallagher, S. How the Body shapes the mind. Oxford, New York: Oxford University Press. 2005.

[23] Merleau Ponty, M. Phenomenology of Perception, trans. C.Smith New York: Routledge 2002, P.140

[24] See Rietveld, E. "Situated Normativity: The Normative Aspect of Embodied Cognition in Unreflective Action". Mind 117(468):2008, 973-1001.

[25] See Carman, T. "The body in Husserl and Merleau Ponty". Philosophical Topics 27(2): 1999, 205-226.

[26] Merleau Ponty, M. Op. Cit., 2002, P.159.

\section{REFERENCE}

[27] Bower, M. and Gallagher. S, "Bodily Affects as Prenoetic Elements in Enactive Perception". Phenomenology and Mind 4: 2013, P.109-131 Drey fus, H.L. "Merleau-Ponty and Recent Cognitive Science". In T. Carman and M. Hansen (eds.), The 
Cambridge Companion to Merleau-Ponty. Cambridge University Press. 2005

[28] Hurley, S. Consciousness in Action Cambridge, MA: Harvard University Press. 1998

[29] Kelly S.D."Merleau-Ponty on the Body" Ratio15(4):2002, P.376391
[30] Noe,A.Action in Perception.Cambridge MA: MIT Press. 2004

[31] Stumpf. S.E. Philosophy: History and Problems, fifth edition U.S.A: McGraw Hill, Inc., 1994

[32] Thompson, E. "Sensorimotor Subjectivity and the Enactive Approach to Experience". Phenomenology and the Cognitive Sciences 4(4): 2005, P 407-427 